\title{
FRONTLINE
}

\section{Bearing Witness 2017 Year 2 of a Pacific climate change storytelling project case study}

\begin{abstract}
In 2016, the Pacific Media Centre responded to the devastation and tragedy wrought in Fiji by Severe Tropical Cyclone Winston by initiating the Bearing Witness journalism project and dispatching two postgraduate students to Viti Levu to document and report on the impact of climate change (Robie \& Chand, 2017). This was followed up in 2017 in a second phase of what was hoped would become a five-year mission and expanded in future years to include other parts of the Asia-Pacific region. This project is timely, given the new 10-year Strategic Plan 2017-2026 launched by the Secretariat of the Pacific Regional Environment Programme (SPREP) in March and the co-hosting by Fiji of the UN Framework Convention on Climate Change (COP23) climate change conference in Bonn, Germany, during November. The students dispatched in 2017 on the 'bearing witness' journalism experiential assignment to work in collaboration with the Pacific Centre for the Environment and Sustainable Development (PaCE-SD) and the Regional Journalism Programme at the University of the South Pacific included a report about the relocation of a remote inland village of Tukuraki. They won the 2017 media and trauma prize of the Asia-Pacific Dart Centre, an agency affiliated with the Columbia School of Journalism. This article is a case study assessing the progress with this second year of the journalism project and exploring the strategic initiatives under way for more nuanced and constructive Asia-Pacific media storytelling in response to climate change.
\end{abstract}

Keywords: bearing witness, climate change, COP23, environmental journalism, Fiji, Pacific Islands, Pacific Regional Environment Programme, SPREP, storytelling

\section{DAVID ROBIE}

Pacific Media Centre, Auckland University of Technology

\section{Introduction}

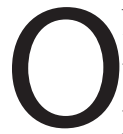

NCE upon a time,' began a post-COP23 New York Times analysis rather whimsically, 'all the countries of the world tried to get together to save the planet from climate change' (Webster, 2017). The problem was, admitted 
the Times, the nations 'couldn't stop sniping at each other'. So they put forward a novel solution by 'telling each other stories in an attempt to cut carbon emissions'.

This was the New York Times' manner of introducing the notion of talanoa, a traditional Fijian and wider Pacific practice of negotiation. The article headline declared both optimistically and rather glibly 'Fijian storytelling can save world'. Opinions have been divided on the success of Fiji as the first Small Island Developing State (SIDS) to co-host the UN Framework Convention on Climate Change (COP23) and while some criticise the failure of President Voreqe Bainimarama to meet some of the predicted objectives (COP23 president, 2017; Darby, 2018; Morgan, 2017; Prasad, 2017), there has been cautious optimism about talanoa as potentially providing a chance for developing countries to have a greater say going forward to 2020 when the Paris Agreement formally takes effect. Reported Carbon Brief:

With Fiji being the first small-island state to host the climate talks, hopes were high that it would give added impetus to the negotiations. High-level speakers ... were preceded by a speech from a 12 -year-old Fijian schoolboy named Timoci Naulusala, who reminded delegates that 'it's not about how, or who, but it's about what you can do as an individual'. (Timperley, 2017)

According to climate analyst Jocelyn Timperley, two outcomes from COP23 in Bonn in November 2017 were regarded as 'significant achievements' by Fiji. These were a Gender Action Plan (UNFCCC, 2017a), which 'highlights the role of women in climate action and promotes gender equality in the process', and the Local Communities and Indigenous Peoples Platform (UNFCCC, 2017b), which aims to support an exchange of experience and sharing of 'best practices on mitigation and adaptation'. Fiji also launched the Ocean Pathway Partnership (COP23.com, n.d.) in a bid to boost the inclusion of oceans within the UN climate change framework. However, Timperley (2017) also noted the reconfiguring of the 'facilitative dialogue' as the 'talanoa dialogue', a one-off process in 2018 (Figure 1): 'This was to reflect a traditional approach to discussions used in Fiji for an "inclusive, participatory and transparent" process.'

The notion of talanoa as a qualitative research and communication tool is widely adopted in a Pacific context. It is also used in a media and journalism storytelling context (Robie, 2013; Ugavule, n.d.). As defined by Seu'ula Johansson-Fua within the Kakala Research Framework of the University of the South Pacific,

Talanoa is a generic term referring to a conversation, chat, sharing of ideas and talking with someone. It is a term shared by Tongans, Samoans, and Fijians. Talanoa can be formal, as between chiefs and his or her people, and it can be informal, as between friends in a kava circle. Talanoa is 


\section{Figure 1: The Talanoa Dialogue}

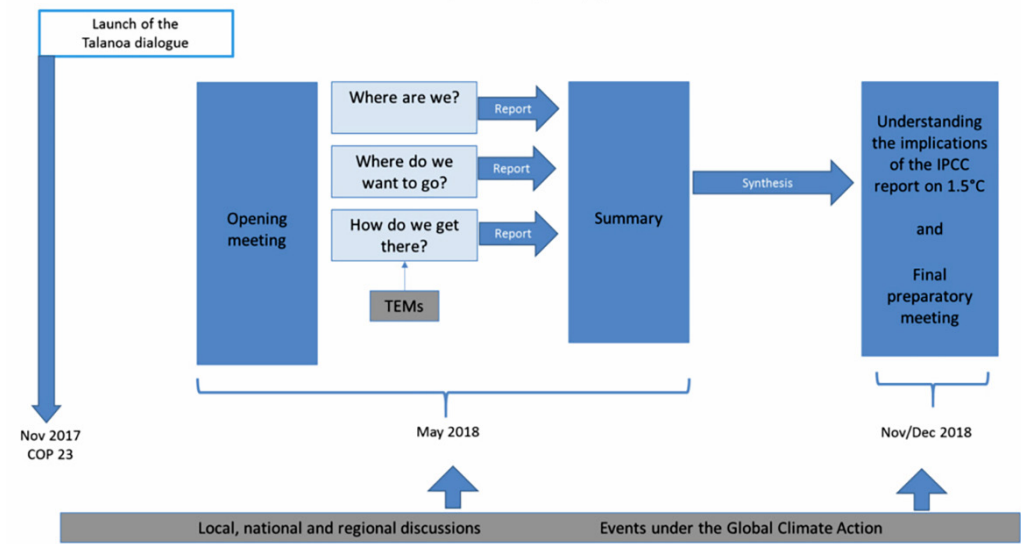

Note: The Talanoa Dialogue leading up to COP24 in Poland in November/December 2018.

also used for different purposes; to teach a skill, to share ideas, to preach, to resolve problems, to build and maintain relationships, and to gather information. (Johansson-Fua, 2014, p. 56).

Leading into the COP23 conference, Bainimarama had made a plea for climate cooperation in a speech at the UN General Assembly in New York in September 2017,referring to a Fijian drua, or traditional oceangoing craft. 'We are all in the same canoe together,' he said (Darby, 2017). Pointing to the catastrophic Hurricane Irma that had ravaged the eastern Caribbean and Florida in mid-August, followed within days by another category 5 Hurricane Maria that struck Dominica and Puerto Rica, Bainimarama urged leaders to consider the toll of ignoring climate change. By preserving narrow national interests, everybody would lose: 'We will be powerless to protect our own people from the consequences of climate change' (Ibid.).

Fiji had just the previous year suffered its own devastating Severe Tropical Cyclone Winston, the worst storm ever in the South Pacific, and second strongest cyclone to make landfall after Super Typhoon Haiyan in the Philippines in 2013. When category 5 Winston savaged Fiji on 20 February 2016, it whipped up winds of 300 kilometres an hour when it came ashore on Koro Island, situated between the main islands of Vanua Levu to the east and Viti Levu to the west (Climate Council, 2016; Tropical Cyclone Winston slams Fiji, 2016). Typically, cyclones approach Fiji from the west, but Winston left its trail of destruction starting from the east. Many villages were flattened and islands flooded by storm surges. According to the Fiji government's Post-Disaster Needs Assessment Report released three months after the cyclone struck, 542,000 people - equivalent to 62 percent of the total populationhad their lives impacted on, with 44 deaths being confirmed (Fiji Government, 2016). 
The storm brought down the power and communications systems linking the islands, with approximately 80 percent of the population losing power, including the entire island of Vanua Levu....Entire communities were destroyed and approximately 40,000 people required immediate assistance following the cyclone. [Also] 30,369 houses, 495 schools and 88 health clinics and medical centres were damaged or destroyed. (Ibid.)

The scale of devastation also highlighted the shortcomings of media reportage of extreme weather and climate change globally with one analyst, US Public Citizen's climate director David Arkush stressing that the following year 2017 was when 'climate change began to spin out of control' (cited by Johnson, 2018) while the media failed to 'connect the dots on evidence right in front of our faces' (Temple, 2018). It was a year that experienced 'record-shattering hurricanes, enormously destructive wildfires, and extreme droughts' (Johnson, 2018). In New Zealand, the Science Media Centre (2018) noted in response to world extreme weather reports (NIWA, 2017; IPCC, 2017) that the year was the fifth-warmest on record for the past century with all five of these years being within the last two decades, 'consistent with the greenhouse-warming trend that we see globally'.

In response to the devastation and tragedy wrought in Fiji by Cyclone Winston, the Pacific Media Centre initiated the Bearing Witness journalism project and despatched two postgraduate students to Viti Levu to document and report on the impact of climate change in April 2016 (Robie, 2016; Robie \& Chand, 2017). This was followed up a year later in April 2017 in the second phase of what was hoped would become a five-year mission and expanded in future years to include other parts of the Asia-Pacific region (Asia Pacific Report, 2017; Robie, 2017). This project is timely, given the new 10-year Strategic Plan 2017-2026 launched by the Secretariat of the Pacific Regional Environment Programme (SPREP launches new 10-year strategic plan, 2017; SPREP Strategic Plan 20112015, 2011; SPREP Strategic Plan 2017-2026, 2017) in March 2017 and the co-hosting by Fiji of COP23 climate change conference in Bonn. The students dispatched in 2017 on the 'bearing witness' journalism experiential assignment to work in collaboration with the Pacific Centre for the Environment and Sustainable Development (PaCE-SD) and the Regional Journalism Programme at the University of the South Pacific included in their reportage a multimedia package about the relocation of a remote inland village of Tukuraki (Hutt \& Cleaver, 2017b) (Figure 2). This article is a case study, another in the series of Frontline journalism-as-research projects, this time assessing the progress with this second year of Bearing Witness and exploring the strategic initiatives under way for more nuanced and constructive Asia-Pacific media storytelling in response to climate change. 


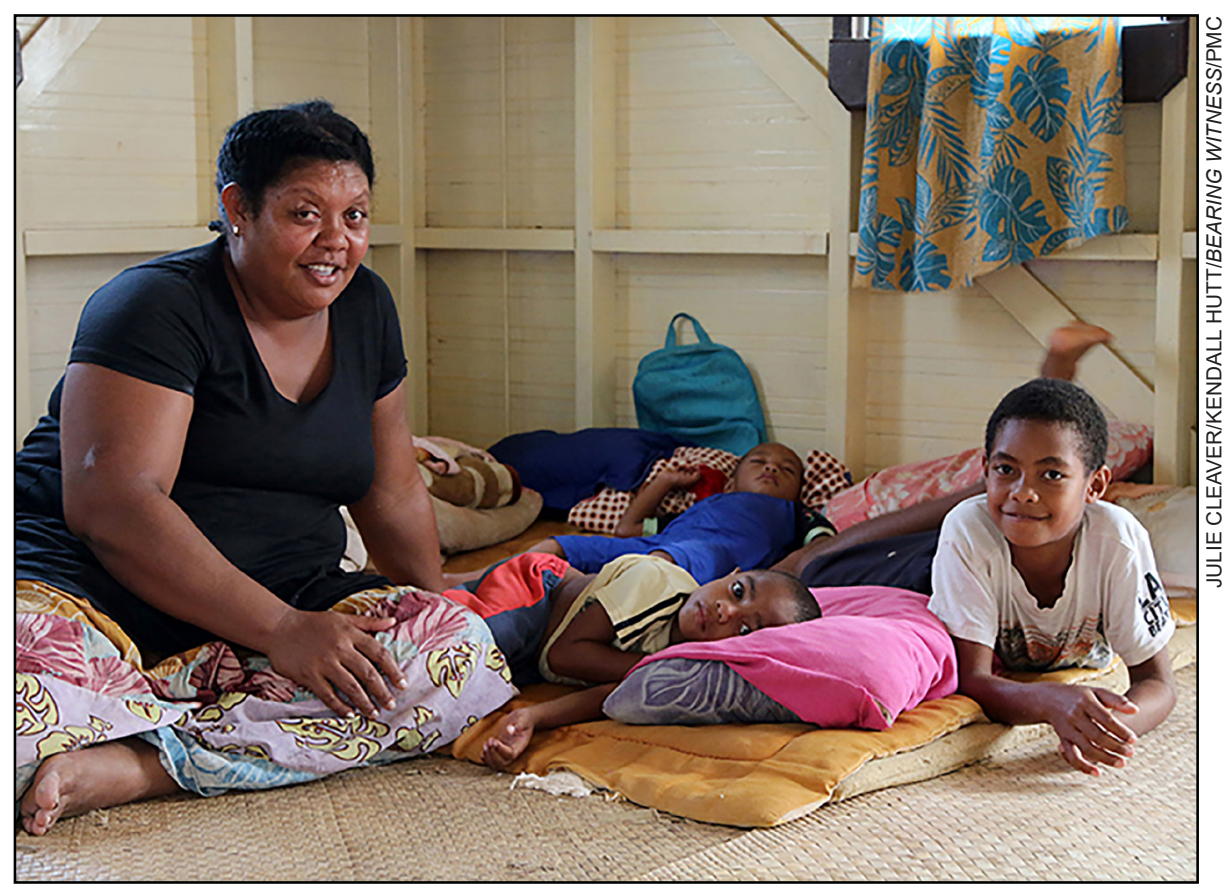

Figure 2: Vilimaina Botitu and three of her children in the Viti Levu village of Tukuraki.

\section{Rationale and methodology}

Climate change is the most serious challenge confronting the microstates of the South Pacific. At least three Pacific Island states, Kiribati, Marshall Islands and Tuvalu, are regarded and frequently cited as the 'frontline' of global climate change in a struggle against 'carbon colonialism' (Dreher \& Voyer, 2015; Robie, 2011, 2014, 2017a; Walsh et al., 2011,; Burnside-Lawry et al., 2017). Western media, particularly in Australia and New Zealand, have produced reportage lacking in substance and nuance when tackling climate change in the Pacific (Nash, 2015). What is published or broadcast tends to be 'framed in ways that centre the interests and concerns of more powerful countries' (Dreher \& Voyer, 2015 , p. 58). Dominant frames portray small island states as 'proof' of climate change, as 'victims' of climate change, as 'climate refugees, and as 'travel destinations' (p. 59). Whereas preferred frames by Pacific Islanders themselves are in more positive terms such as human rights, climate justice and innovative and adaptive responses.

While framing is widely regarded as the most common conceptual tool applied to climate change communication, including with news media coverage (Gunster, 2017; Hackett at al., 2017; Olausson, 2011), it is insufficient alone as a strategic approach. Climate change is not just a scientific, technical 
or economic issue, argues Canadian journalism professor Robert A. Hackett. It poses profoundly ethical and political challenges to human institutions, including journalism (Hackett et al., 2017, Singh, 2017). Another Canadian, Shane Gunster, argues that instead of focusing scholarly analysis on the science of climate change, it would be more effective for civil engagement if the focus was on the framing of climate politics (Gunster, 2017, p. 59). Gunster argues that climate justice 'defines the root cause of climate change not as emissions but as inequality'. He describes it as structural inequality that 'violates the core normative principle of distributive justice' (p. 62). On top of this, countries that contribute most to this injustice dominate the discourse about mitigation and adaptation while the most vulnerable, such as Pacific nations and other coastal developing nations, have the least resources to adapt to climate change (Loo, 2013; Lugo-Ocando, 2017). .

Hackett has pressed for fundamental shifts in journalism priorities towards 'greening democracy' and has suggested sharing some of the tools characteristic of Peace Journalism (PJ) such as 'an analytical method for evaluating reportage of conflicts, a set of practices and ethical norms that journalism could employ in order to improve itself, and a rallying call for change' (Hutt, 2016; Hackett, 2017; Lynch, 2014; Romano, 2010; Shaw et al., 2011). This approach has also been explored to some degree by Shaw, specifically writing about parallels between Peace Journalism and Human Rights Journalism (HRJ) (Shaw, 2011). There are key challenges for journalism educators too, who need to think outside conformist teaching frameworks and have a radical approach (Ings, 2017), and beyond the 'news from nowhere' pessimism (Lynch, 2014, p. 31). From subtle to obvious shifts in wording with climate change stories, argues cultural politics of climate analyst Maxwell T. Boykoff, media portrayals possess great potential to influence reader perceptions and concern. Critiquing the notion of 'who speaks for the climate', he says that in turn, these media changes can feed into public awareness and engagement, as well as politics and policy (Boykoff, 2011, p. 11). Singh (2017) argues for less 'gratuitous coverage given to presidents, prime ministers, diplomats, heads of regional organisations and other bureaucrats' which needs to be balanced with in-depth coverage of grassroots people who are actually experiencing the effects of climate change first-hand. Former President Anote Tong of Kiribati reflects this message in the eloquent documentary Anote's Ark (2018) about the fate of his nation of 115,000 people in which he hopes to 'rouse world leaders from their inaction'.

The Bearing Witness project has also related well to a journalism-as-research strategy (Bacon, 2012; Das et al., 2010; Nash, 2015, Nash, 2017) and a 'bottom up' approach with marginalised groups (Harris, 2014). Nash, for example, analyses 'silences and absences' as the norm for 'those not in a position to exercise power in the world of journalism', which are often present in conflicts of 
interpretation (2017, p. 147). Drawing from historian Michel-Rolph Trouillot's observations on 'truth-seeking practices' (p. 145), he stressed the 'making of contemporary significance' stage in this process. In a Pacific context, the project has used the 2015-2026 SPREP Pacific Plan as a touchstone in the context of a challenge to journalists to play a greater role in communication about climate change resilience and human rights in the region. The Pacific Media Centre developed a plan for a two-week climate change field trip for two postgraduate student/graduate journalists to gain firsthand experience of reporting on climate change issues in Fiji in April 2017. Drawing on previous field trips organised by the PMC, including the 2016 Bearing Witness mission and the experience of journalism programmes at institutions such as a 2015 New Caledonia and Vanuatu reportage by Queensland University of Technology (Duffield, 2016), this was an exercise in professional development. Fiji was selected for the climate project for logistical and media resource reasons, given that the centre already had a long-established relationship with the USP regional Pacific journalism programme with available accommodation on the Laucala Bay campus close to the centre of environmental research. Also, USP is currently engaged in a major Pacific-wide climate change baseline media research project and there was a synergy between these two initiatives.

Another partner at USP was the Pacific Centre for Environment and Sustainable Development (PaCE-SD), which was established as a centre of excellence in 1999 for 'environmental education, research and community engagement' in the Pacific region. The director, 2010 Nobel Peace Prize co-laureate Professor Elisabeth Holland, has led the centre in carrying out environmental and climate change research to 'empower [Pacific] people with the adequate knowledge to be able to adapt to the impacts of climate change and to also pursue sustainable development' (About us, n.d.). Communications officer Sarika Chand was the principal collaborator for the project.

The PMC project adopted the name 'Bearing Witness', drawing on the Quaker tradition of taking action over 'truth' based on conscience and being present at the sites of injustice. This seemed highly appropriate given that the field trip was seeking to provide an alternative framing of climate change journalism in terms of resilience and human rights. An inspiring example of this 'bearing witness' frame for climate change is the Collectif Argos (2010) photojournalism portfolio on climate refugees, many of the images were portrayed in their book of the same name. The concept is also widely adopted by environmental groups, such as Greenpeace. According to a definition by Gray Cox in his Pendle Hill Pamphlet,

Quakers view truth as something that happens, it occurs ... truth is not a dead fact which is known: It is a living occurrence in which we participate ... the guiding concern of people bearing witness is to live rightly, in ways that are exemplary. (Cox, 1985) 


\section{Bearing Witness 2017 project video outputs}

'We're running out of time' (2min57sec): Bearing Witness 2017 BCS (Hons) graduate journalist Kendall Hutt and Julie Cleaver talk to Pacific Media Centre director Professor David Robie about the climate change project in 2016, reviewing progress, the objectives and the plan for 2017.

Reporter: Kendall Hutt

Camera/editor: Julie Cleaver

www.youtube.com/watch?v=R7Mhg33-67A

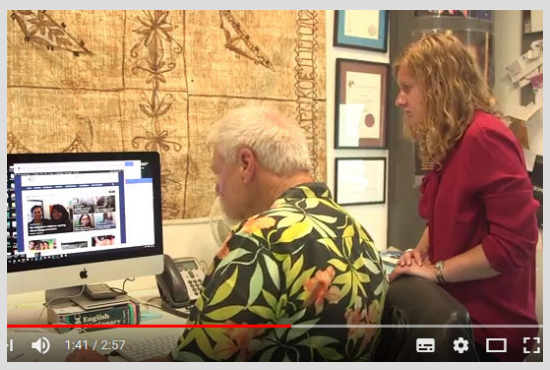

Pacific climate expert says report will help countries meet targets (1min32sec): The commitment of more than 190 nations to reducing global emissions will continue to be addressed following a special climate change report. Resource: Dr Morgan Wairiu, an expert in food security and climate change with USP's Pacific Centre for Environment and Sustainable Development (PaCE-SD), was a lead author of the report.

Reporter: Kendall Hutt

Camera/editor: Julie Cleaver.

www.youtube.com/watch?v=zrlOJAwx4HA

USP student journalist voices on climate change (2min 47sec): Pacific journalism students in Fiji say reporting climate change is crucial for survival of the region. USP students say educating people about the issue throughout the region is a key factor when it comes to serving the Pacific.

Reporter: Kendall Hutt

Camera/editor: Julie Cleaver.

www. youtube. com/watch? $v=$ gasKsJ1rA7Y

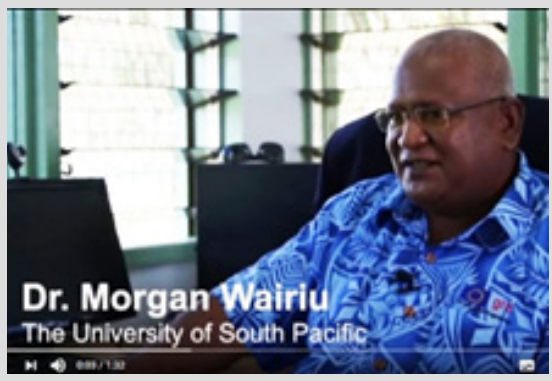

Fiji's Tukuraki after the landslide (3min28sec): In January 2012, Tukuraki village on Viti Levu was almost wiped out by a deadly landslide. Tukuraki was then hit by Cyclone Evan. Four years later, Tukuraki was again devastated by Tropical Cyclone Winston, scattering the community. The inland village near $\mathrm{Ba}$ is now in the process of relocating.

Reporter: Kendall Hutt

Camera/Editor: Julie Cleaver.

www.youtube.com/watch?v=G0weZjJiK-I
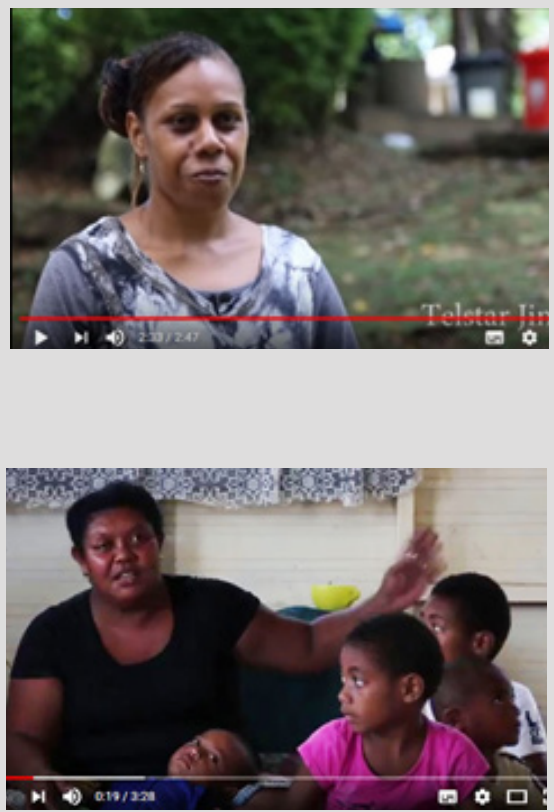


\section{The project-Bearing Witness: Experiential climate change journalism}

As in 2016, two student journalists, or rather one student journalist completing an honours year and a journalist who graduated with an honours degree within four months of the end of the project, were selected for the 14-day second year mission between April 17-30, 2017. At the time of the project, Kendall Hutt was contributing editor of the Pacific Media Centre's Pacific Media Watch freedom project (www.pacmediawatch.aut.ac.nz). She had gained her Bachelor of Communication Studies degree with a major in journalism in 2015. The following year she was awarded an Honours degree in Communication Studies and also won an Inclusive Journalism Initiative (IJI) exchange trip to Finland in 2016. She topped her year in the Asia Pacific Journalism Studies course, saying she was 'captivated' doing Pacific stories after reporting on media freedom in the region.

Julie Cleaver completed her Bachelor of Communication Studies degree in 2016 and travelled to Denmark and gained first class honours in fourth BCS year. Although she did not undertake the Asia Pacific Journalism Studies paper as other Bearing Witness students have done, she had an internship with RNZ Pacific in 2016 and a strong interest in climate change and Pacific issues: 'While there I found, voiced and wrote articles about domestic violence in Fiji, protesters in American Samoa and developments in the Marshall Islands. I also used my Bahasa Indonesian language skills to track down sources in West Papua and Indonesia for other reporters.'

Ironically, as Hutt and Cleaver were preparing to leave for Fiji, weather authorities were issuing cyclone warnings that recalled the threat of TC Winston the year before. Asia Pacific Report said: 'As schools, universities and other educational centres closed early today in the face of warnings over high winds and power outages with the full force of Cyclone Cook bearing down on New Zealand, the Pacific Media Centre confirmed its climate change Bearing Witness project would go ahead this weekend' (Asia Pacific Report, 2017).

Hutt and Cleaver arrived in Suva, Fiji, on 17 April 2016, during Easter weekend. They faced a challenge in making contact with the project partners at the University of the South Pacific, but were given an early briefing by Sarika Chand, communications officer at the Pacific Centre for Environment and Sustainable Development (PaCE-SD).

The Bearing Witness project team's first assignment was reporting on April 18 about a Pacific Centre for Environment and Sustainable Development (PaCE-SD) seminar addressing 'Disaster risk reduction from a physical planning perspective: Fiji'. Joeli Varo, a Lands Officer for the government's Sustainable Land Use Planning and Development Unit, argued that there were two ways in which Fiji could both mitigate and adapt to flooding. These involved 'hard measures', such as sea walls, and 'soft measures', such as ensuring compliance with building regulations. He said: 
I would say we need a combination of both, because in our urban areas they need hard structures - they need sea walls because we cannot do soft measures in those areas. We cannot plant trees, we cannot retreat, we cannot relocate, and we just have to implement hard measures. For rural area settings, there is still room for relocation and retreat. We can apply soft measures there. (Quoted by Cleaver \& Hutt, 2017)

On April 21, Kendall Hutt filed a report about a talk by the Marshall Islands Students Association (MISA) for Asia Pacific Report critiquing 'current political inaction' towards addressing land-based contaminants in the ocean. According to Brooke Takala, a MISA member and doctoral candidate at the University of the South Pacific who specialises in education for sustainability: 'The time to act is now. We have to act now' (Hutt, 2017a).

MISA had launched a campaign with the hashtag \#MISA4thePacific prior to the lead up to the UN Oceans Conference in New York in June. Supporters were encouraged to submit art, music, photography and poetry urging action over the Sustainable Development Goal 14.1, which seeks to prevent or significantly reduce marine pollution for 2025. Explained Takala:

If we don't prioritise SDG 14.1, all of our other sustainable development goals are moot. There's no point. If we have radiation leaking into our ocean and poisoning our food systems there's no food security, there's no water security, there's no maternal health, there are no opportunities. This has to be prioritised. (Ibid.)

MISA's call to action highlighted the prolonged suffering from radioactive fallout of many Marshall Islanders in the aftermath of post-war United States nuclear testing on Enewatak and Bikini atolls by the US between 1946 and 1962. In 1949, the UN secured an agreement with the United States to govern the islands of Micronesia as the strategic Trust Territory of the Pacific Islands. While governing the Marshall Islands, the US conducted 67 atmospheric and underwater nuclear tests (Robie, 2017a).

More than seven decades on from the first nuclear tests, many islands and atolls in the Marshall Islands remain uninhabitable. During the USP student event, MISA members highlighted an 'inability' to address the large quantities of plutonium leakage from the 46 centimetre thick concrete dome- - known locally as 'The Tomb' — on Runit Island on Enewatak Atoll, which was supposed to have sealed off 84,866 cubic metres of toxic waste left over from 12 years of nuclear and thermonuclear bombs tested by the US (Jose, Wall \& Hinzel, 2015). It was described in a Guardian investigation as appearing like a 'drowned UFO ... underground radioactive waste has already started to leach out of the crater'.

Takala said she wanted the US to finally take stock of its 'unfinished business' 
in the Marshall Islands and recognise that Castle Bravo, a 15-megatonne hydrogen bomb tested on Bikini Atoll in 1954 with a blast 'one thousand times bigger than Hiroshima', was not simply an 'accident' (Hutt, 2017a).

For me personally, as a mother of a young Enewatak boy whose land rights are on that island with a nuclear waste storage site, I want the world to know that the US has stolen my child's future and that they need to be held accountable. And I think when we share that message that it is this child's future, all of our children's futures at stake, and that we cannot let this go. (Quoted by Hutt, 2017a)

On April 22, Hutt and Cleaver profiled with both a text report and video progress on a new climate research report due to be released in 2018 examining the commitment of more than 190 nations to reducing global emissions, and offering advice how countries may be able to further cut emissions (Hutt \& Cleaver, 2017). Dr Morgan Wairiu, a Solomon Islander and deputy director of PaCE-SD, one of only two Pacific Islanders working on the project, said the report would enable countries to augment their efforts in keeping the global average temperature below $1.5^{\circ} \mathrm{C}$. as agreed under the Paris Agreement of the Committee of Parties (COP21). He noted that if current aggregate emission reductions by countries under their Intended Nationally Determined Contributions (INDCs) continued at the current pace, or 'business as usual' as some commentators are saying, a global average temperature would be on track for $2.7^{\circ} \mathrm{C}$. This would have a serious impact on 'frontline' Pacific Island countries.

For Pacific Island countries, because of our vulnerable ecosystems, we can manage up to $1.5^{\circ} \mathrm{C}$, but beyond that we're going to start losing our ecosystems and livelihood, our resources, and then the survival of our people... Some countries will disappear from the face of the world.

In a multimedia report about the views of Pacific journalism students at USP, the four interviewees from three countries (Fiji, Tuvalu and Vanuatu) said reporting climate change was crucial for the 'survival of the region' (Cleaver \& Hutt, 2017b). They added that educating people about the issue throughout the Pacific region and the world would be a key factor when it comes to 'saving' the Pacific. For example, one third-year Fiji student, Shivika Mala, double majoring in journalism and politics, said:

Covering climate change is important for me because my country's life and my country's people's lives are at stake, so I need to let institutions outside my country know that we are facing the effects of climate change, and its severe effects that we're facing.

Climate change is happening. This is the reality and it's about time 
journalists, and other people who don't necessarily believe in climate change, start doing their research and start understanding the challenges, the implications, and the impact it has on not only the Pacific countries, but other countries as well. (Quoted by Cleaver \& Hutt, 2017b)

For Semi Malaki of Tuvalu, who is also studying a double major in journalism and politics in Fiji, climate change has already become a reality in his home country, and the lives of the people has changed:

For us in Tuvalu it's more to do with the security and survival of our people, because we all know climate change causes the sea level to rise. People now are now less dependent on root crops and more dependent on imported foods from overseas, and that's had a lot of impact on our diets. This has health impacts on non-communicable diseases, like lots of Tuvaluans have suffered from diabetes and high blood pressure due to the change in their diets. (Quoted by Cleaver \& Hutt, 2017b)

Cleaver and Hutt's main story came on April 27, after the graduate journalists had travelled more than 215 kilometres to the highlands of Viti Levu near Yakete, $\mathrm{Ba}$, to visit the isolated community of Tukuraki, devastated firstly by a landslide in 2012 which destroyed 80 percent of the village and tragically killed a young family of four people. Anare Taliga (38 years), Mereoni Robe (23 years), Losena Nai (18 months) and Makelesi Matalau (6 months) died in that disaster. 'The landslide also wiped out the village access road, fresh water resources and homes' (Tukuraki village location, 2016). However, that was not the end of Tukuraki's misfortune (Fiji's devastated Tukuraki village moves, 2017). The community was hit by Cyclone Evan just 10 months later, and then in February 2016 it was again struck by Cyclone Winston, the most savage storm recorded in the Southern Hemisphere (Burnside-Lawry et al., 2017). Tukuraki is unique in that it is the only inland village among 48 communities in Fiji designated for priority relocation. All the rest are coastal. A F\$756,000 (NZ\$519,000) relocation project moving the village to a safer and 'less disaster prone' site closer to Nalotawa District School has been financed by the European Union and the ACP Group of States-funded Building Safety and Resilience in the Pacific Project (BSRP) implemented by the Pacific Community. Eleven new homes, a community centre, a retaining wall and playground were built in the new location (Fiji's devastated Tukuraki village moves, 2017).

With assistance from the project management and PaCE-SD's Sarika Chand, Cleaver and Hutt were able to visit the village and carry out interviews and report on the villagers' experiences. 'Being in Fiji, it is clear climate change is not just some phenomenon scientists and politicians debate, it is changing the lives of people in the Pacific,' recalled Kendall Hutt (Hutt, 2017c, p. 3). She considered 
'bringing this reality to the wider public' is really important and especially to people who 'do not necessarily believe climate change is real' in countries such as New Zealand. She added:

I was brought to tears by a Tukuraki villager [Vilimaina Botitu] telling her heart-wrenching story of losing her uncle and his family in a deadly landslide after a week of heavy rain and her community's suffering through six years of limbo as they waited to be relocated. I comforted a journalism student after hearing that her home, the island of Narikoso [Ono island, Kadavu, Fiji] will be swallowed by the sea due to rising levels.(Ibid.)

In an initial story and video filed after the visit to Tukuraki, Cleaver and Hutt reported:

After six years in limbo, the villagers of Tukuraki in the Fiji highlands of $\mathrm{Ba}$ on Viti Levu are three months shy of moving into their new village in July [they did not actually move until October].

Located 10 kilometres from their former village, which was hard-hit by a landslide in early 2012, Cyclone Evan in the same year and Cyclone Winston in 2016, the villagers can now look forward to 10 new homes, a community hall which doubles as an evacuation centre, and a Methodist church.

The new village is located around 60 kilometres north of the selfproclaimed 'sugarcane capital of the world' Lautoka, and allows the villagers to have access to clean, running water, flush toilets, and showers. (Cleaver \& Hutt, 2017c)

Later, after reflecting on their return to Auckland, Cleaver and Hutt reported with a more in-depth feature in both Asia Pacific Report and in the AUT students' magazine Debate on May 6. This was followed up with a mini-documentary in March 2018. The opening sequence of the Debate feature said:

Vilimaina Botitu was fast asleep when the earth from a nearby hill tumbled down, burying her uncle's house in mud, trees and rock.

Her small village of just 10 houses, located in the mountainous highlands of $\mathrm{Ba}$, Fiji, had been pummelled for a week prior to the landslide in January 2012. The people of Tukuraki are no strangers to heavy downpours. Even as we sit cross-legged on a flax-woven mat in Botitu's new temporary home, located just 10 kilometres away from the old village, the rain moves in quickly and heavily, seemingly out of nowhere. But on the day of the landslide, Botitu knew something was wrong.

'I begged Uncle Anare to bring his family to stay with me, because where I live it is safe,' she tells us through tears, but he didn't listen. He just said, "If God thinks it is my time to go, then I am okay with that.", (Cleaver \& Hutt, 2017d) 
Uncle Anare and three family members died that night and Vilimaina Botitu herself is in tears as she recalls that night and her terrible experience of bathing the four members of the Taliga family and preparing them for burial. Her story is poignantly retold in the feature by Cleaver and Hutt, and also by Cleaver's documentary.

\section{Discussion}

The Bearing Witness team worked under considerable pressure while in Fiji. For Julie Cleaver it was especially challenging and rewarding.

As we were only in the country for just under two weeks, we had to film as much as possible in a short amount of time. This meant that every day was filled with interviews, editing and meeting different people. Sometimes we would wake up at $8 \mathrm{am}$ and go to sleep at $11 \mathrm{pm}$ as we were up all night editing videos - but this was a lot of fun. (Cleaver, 2017).

For both Cleaver and Hutt, the mission demonstrated that climate change was not just an abstract issue, but a 'lived' and 'daily' experience for many Fiji islanders. There was an impression in New Zealand that they were 'removed from the human element' of the issue. Out of the Pacific, the issue was too often lumped as 'extreme weather patterns, non-governmental pressure on political powers and the urging by scientists to take more notice' (Hutt, 2017c). However,

when you are on the ground in the Pacific, you are confronted by people's emotions, so you truly understand the real-life effects of climate change. You know that people in the Pacific are losing their islands, their homes and everything that goes with it: lifestyle, identity, culture and legacy. (Hutt, 2017c)

Hutt felt guilty coming from New Zealand and was apologetic about the 'actions of my Western, industrialised country and its seeming drill, frack [and] mine policy'. She recalls that she had difficulty knowing that her country, and others, and 'perhaps, my lifestyle' were such 'tangible, seemingly irreversible effects' of the Pacific way of life.

I personally cannot fathom facing this reality, but for people in the Pacific it is already a reality and they are adapting to climate change. They are not victims. Governments are relocating people inland and, in extreme cases, to other islands in the Pacific, despite knowing that that country may well suffer the same fate in time. (Hutt, 2017c)

A priority of the project in future is to ensure that the Bearing Witness teams give maximum effort to community visits. It is essential to 'witness' climate change by experiencing the 'most vulnerable and hard-hit' areas. 
Moving from being 50 minutes out of Suva [in 2016] to over five hours northwest with the project this year made a difference to the scope of stories we were hearing and telling. We heard from villagers from the remote community of Tukuraki, who are the first inland village to be relocated due to climate change in a unique move by the Fijian government. (Hutt, 2017).

Ideally, future editions of this Bearing Witness project could share the experiences and stories of communities in Fiji's more remote islands and in other Pacific countries. At the very least, expanding the project to include a different location every year would be an advantage, and possibly increasing the numbers of teams involved, would be a strong contribution. This would help understanding of the impact of climate change in the Pacific - 'not just a snapshot from one country'.

Six months after the Bearing Witness mission to Tukuraki, the community shifted to their new category five cyclone-standard village, a model for relocation, and it was officially opened on October 29. Inia Seruiratu, High Level Climate Change Champion for COP23 and Minister for Agriculture, Rural and Maritime Development, and National Disaster Management and Meteorology, said: 'The achievement of creating a disaster resilience of the community that has been led by the community itself is testament to the resilience of the Tukuraki' (Fiji's devastated Tukuraki village moves, 2017). Pacific Community Deputy DirectorGeneral Dr Audrey Aumua added: 'This community knows and understands disaster but what makes this relocation remarkable is the partnership led by the Fiji government with SPC and the European Union to achieve real, measurable disaster resilience at the community level' (Ibid.)

A footnote to the mission was the Bearing Witness team Julie Cleaver and Kendall Hutt winning the 2017 Trauma Journalism award by the DART AsiaPacific agency, a component of the Colombia Graduate School of Journalism. Judge Cait McMahon noted: 'Cleaver and Hutt's victim-focused story of climate change in Fiji through the eyes of one woman and her family's tragedy was sensitive, well researched and of a high professional standard. Hearing the survivor's voice without interference from the journalist resulted in a well-produced and intelligently edited piece.' (Dart AsPac, 2017)

\section{Conclusion}

Climate Crisis journalism is one way democracy and journalism strive to face up to the planetary emergency now upon us. The Bearing Witness project is a successful way of 'greening' media initiatives to engage with this challenge. This project adopts a methodology that has evolved out of the Peace Journalism model. However, it can be equally argued that the Bearing Witness project in Fiji is also well anchored in the context of Human Rights Journalism and 
Climate Justice as metaframes. Two years into the project, the strengths remain:

- enabling climate change and environmental issues to be covered more thoroughly and in-depth;

- enabling student journalists from different cultural, educational and professional backgrounds to provide new perspectives and renewed enthusiasm in the way some issues are reported;

- providing a more enriching experience for the journalists to be able to report on climate change and environmental issues first hand;

- strengthening relations between collaborating agencies - such as PaCE, Auckland University of Technology, the USP Journalism School, AUT's documentary collective Te Ara Motuhenga and the Pacific Media Centre - and laying a foundation for timely collaborations on the climate given the crisis being faced globally;

- fulfilling the need for the media to exercise its role as gatekeepers, educators, and disseminators of correct climate information for community awareness and advocacy;

- enabling the environment to have a higher profile after being sidelined for so long by neoliberal politics and economics in the newsroom; and promoting the establishment of a 'climate crisis team', giving priority to a sector, which newsrooms and individuals need to realise, affects all the other rounds or beats, such as economy, health, and human rights.

Instilling this crisis framing into journalists as students is a great start. As observed by Nash (2017, p. 148), journalism has a role not only in producing verifiable knowledge as part of the future historic record, as 'the first draft of history' as he points out, but also conversely in the analysis and making of 'contemporary significance' and challenging of silences around climate change. The value of a journalism project like this evolving over a five-year period in the $\mathrm{Pa}$ cific region is important. If it remained as just a one-off initiative, much would go uncovered by overstretched mainstream media organisations in Australia and New Zealand, for example, which have a long record of under reporting the Pacific, and it would not happen at all.

However, on the downside, the limited funding available for a project like this is still an inhibiting factor that limits the project achieving its full potential. It is hoped that more generous funding can be accessed in future to expand the project into a multi-country project to generate a series of documentaries as 'living' documentation of the Climate Crisis in the Pacific. Greater effort needs to be made for more compelling storytelling strategies to make climate change appear more real for neighbouring countries, such as Australia and New Zealand, 
rather than being removed and abstract. While the questions of Pacific leaders' commitment about climate change continue, in spite of impressive initiatives like Voreqe Bainimarama with COP23 and the talanoa dialogue, journalists and journalism must play their role.

One Pacific leader in particular has been walking the talk. It is fitting that the last word for journalism and journalists in this article comes from former Kiribati President Anote Tong, whose government has bought a slice of Fiji land as a potential larder for his people, or even destined to be a place to live when they are eventually forced to become climate refugees. At the Sundance Film Festival screening of his documentary in January 2018 (Anote's Ark), Tong greeted a standing ovation by saying:

[Climate change] isn't an academic exercise for me. It's highly emotional. I'm looking at my grandchildren, asking myself what is to become of them. It's not something I enjoy doing or think is fun. It's something that is absolutely necessary.

It's getting desperate. Solutions continue to be evasive. People regard [climate change] as something that may or may not happen, but the science is categorical: it's happening.

I was just asked by a journalist recently, 'What are you going to do about it?' I said, 'What are you going to do about it?'”

\section{Resources}

Bearing Witness Project reports 2016 and 2017 http://asiapacificreport.nz/category/ climate/bearing-witness/

Full matrix of published and broadcast stories: Appendix 1 (p. 177)

Image gallery: Bearing Witness crew go to market on Fiji campus

https://asiapacificreport.nz/2017/04/20/gallery-bearing-witness-crew-go-to-marketon-fiji-campus/

\section{Videos produced}

Cleaver, J., \& Hutt, K. (2017, April 12). Pacific climate Bearing Witness 2017 [Video, $2 \mathrm{~m} 57 \mathrm{~s}]$. https://www.youtube.com/watch?v=R7Mhg33-67A

Cleaver, J., \& Hutt, K. (2017, April 21). Pacific climate change expert says report will help countries meet their targets. [Video, $1 \mathrm{~m} 32 \mathrm{~s}]$. Available at https://www.youtube. $\mathrm{com} / \mathrm{watch}$ ? $\mathrm{v}=\mathrm{zrlOJ}$ Awx $4 \mathrm{HA}$

Cleaver, J., \& Hutt, K. (2017, April 24). USP student journalist voices on climate change. [Video, $2 \mathrm{~m} 47 \mathrm{~s}$ ]. Available at https://www.youtube.com/watch? $=$ gasKsJ1rA7Y

Cleaver, J., \& Hutt, K. (2017, May 8). Fiji's Tukuraki after the landslide. [Video, 3min28]. Available at https://www.youtube.com/watch? $v=$ Pux-jdCOOjE 


\section{References}

About us. (n.d.). Pacific Centre for Environment and Sustainable Development (PACESD). Retrieved from http://pace.usp.ac.fj/ABOUTUS.aspx

Anote's Ark (2018). Director: Matthieu Rytz. EyeSteelFilm [Documentary film]. www. eyesteelfilm.com/anotesark

Asia Pacific Report (2017, April 13). AUT journalists head off to Fiji for Bearing Witness project. Retrieved from https://asiapacificreport.nz/2017/04/13/aut-journalists-headoff-to-fiji-for-bearing-witness-climate-project/

Bacon, W. (2012). Frontline: An innovative direction in academic journalism. Pacific Journalism Review: Te Koakoa, 18(2), 153-165. doi: 10.24135/pjr.v18i2.270

Boykoff, M. T. (2011). Who speaks for the climate? Making sense of media reporting on climate change. Cambridge, UK: Cambridge University Press.

Burnside-Lawry, J., Franquet, R. , Wairiu, M., Holland, E., \& Chand, S. (2017).Communication, collaboration and advocacy: A study of participatory action research to address climate change in the Pacific. The International Journal of Climate Change: Impacts and Responses, 9(4), 11-33.

Campbell, J. , \& Barnett, J. (2010). Climate change and small island states: Power, knowledge and the South Pacific. London, UK: Taylor \& Francis.

Cleaver, J. (2017, December 31). The graduate reflections: Julie Cleaver. In Robie, D., Bearing Witness 2017: A Pacific Media Centre/Te Ara Motuhenga project (pp. 6-7). Auckland: Pacific Media Centre, Auckland University of Technology

Cleaver, J., \& Hutt, K. (2017a, April 18). Fiji needs better urban planning to reduce climate change impact, says researcher. Asia Pacific Report. Retrieved from https:// asiapacificreport.nz/2017/04/18/fiji-needs-better-urban-planning-to-reduce-climatechange-impact-says-researcher/

Cleaver, J., \& Hutt, K. (2017b, April 25). Pacific students passionate about reporting climate change. Asia Pacific Report. Retrieved from https://asiapacificreport. nz/2017/04/25/pacific-student-journalists-passionate-about-reporting-climate-change/

Cleaver, J., \& Hutt, K. (2017c, April 27). Village relocation provides new hope for Fiji's devastated Tukuraki. Asia Pacific Report. https://asiapacificreport.nz/2017/04/27/ village-relocation-provides-new-hope-for-devastated-tukuraki/

Cleaver, J., \& Hutt, K. (2017d, May 6). Destruction and Construction: The story of Tukuraki village. Debate. Retrieved from the Pacific Media Centre at http://www.pmc. aut.ac.nz/sites/default/files/file_bin/201706/Tukuraki\%20Village\%20Feature\%20 Debate\%20Issue\%206\%20May\%202017.pdf

Climate Council. (2016, February 26). Was cyclone Winston influenced by climate change? ClimateCouncil.org. Retrieved from https://www.climatecouncil.org.au/ cyclone-winston-and-climate-change

Collectif Argos. (2010). Climate refugees. Introductions by Hubert Reeves and Jean Jouzel. Boston: Massachusetts Institute of Technology.

COP23 President Bainimarama to 'reach out' to Trump over climate. (2017, February 9). Asia Pacific Report. Retrieved from http://asiapacificreport.nz/2017/02/09/cop23president-bainimarama-to-reach-out-to-trump-over-climate/

COP23.com (n.d.). The ocean pathway: A strategy for the ocean into COP23 - towards an ocean inclusive UNFCCC process. Retrieved from https://cop23.com.fj/the-oceanpathway/

Cottle, S. (2009). Preface: Global crises and the media. In Boyce, T., \& Lewis, J., Climate change and the media. Oxford: Peter Lang.

Cox, G. (1985). Bearing witness: Quaker process and a culture of peace. Pendle Hill 
Pamphlet \#262. Wallingford, PA: Pendle Hill.

Darby, M. (2017, September 21). Fiji's climate leadership: 'We are all in the same canoe'. Climate Home. Retrieved from www.climatechangenews.com/2017/09/21/ fijis-climate-leadership-canoe/

Darby, M. (2018, March 9). Fiji climate lead challenged Western consultants' influence before losing job. Asia Pacific Report. Retrieved from https://asiapacificreport.nz/2018/03/09/ fiji-climate-lead-challenged-western-consultants-influence-before-losing-job/

Dart AsPac honors Pacific Media Centre with Trauma award (2017, December 12). DartCenter.org [Blog]. Retrieved from https://dartcenter.org/blog/2017/12/dart-aspachonors-pacific-media-centre-trauma-award

Das, J. , Bacon, w., \& Zaman, A. (2010). Covering the environmental issues and global warming in Delta land: A study of three newspapers. Pacific Journalism Review, 16(1), 10-33.

Dreher, T., \&, Voyeur, M. (2015). Climate refugees or migrants? Contesting media frames on climate justice in the Pacific. Environmental Communication: A Journal of Nature and Culture, 9(1), 58-76. Doe: 10.1080/17524032.2014.932818

Duffield, L. (2016). New Caledonia and Vanuatu: Differences defined in a studentreporting venture into the Pacific. Pacific Journalism Review, 22(1), 137-151. doi: $10.24135 /$ pjr.v22i1.17

Fiji Government (2016, May). Fiji: Post-Disaster Needs Assessment: Tropical Cyclone Winston, February 20, 2016. Retrieved from https://reliefweb.int/sites/reliefweb.int/ files/resources/Post $\% 20$ Disaster $\% 20$ Needs $\% 20$ Assessments $\% 20$ CYCLONE $\% 20$ WINSTON\%20Fiji\%202016\%20\%28Online\%20Version\%29.pdf

Finau, G., Cox, J., Tarai, J., Kant. R., Area, R., \& Titifanue, J. (2018). Social media and disaster communication: A case study of Cyclone Winston. Pacific Journalism Review, 24(1), 123-137.

Gunter, S. (2017). Engaging climate communication: Audiences, frames, values and norms. In Hackett, R. A., Forde S., Gunter, S., \& Foxwell-Norton. (Eds.). Journalism and climate crisis: Public engagement, media alternatives (pp. 49-76). Abingdon, OX: Routledge.

Hackett, R. A. (2017). Can peace journalism be transposed to climate crisis news? Pacific Journalism Review, 23(1), 14-24.doi: 10.24135/pjr.v23i1.100

Hackett, R. A., Forde S., Gunster, S., \& Foxwell-Norton. (eds.) (2017). Journalism and climate crisis: Public engagement, media alternatives. Abingdon, OX: Routledge.

Harris, U. (2014). Engaging communities in environmental communication. Pacific Journalism Review: Te Koakoa, 23(1), 65-79. doi: 10.24135/pjr.v23i1.211

Hay, J. (2017, June 11). Fiji ups the temperature at COP23 with call to action. GlobalCapital. Retrieved from https:/www.globalcapital.com/article/b155rckpd8p7c4/fiji-upsthe-temperature-at-cop-23-with-call-to-action

Hutt, K. (2016). Call for new media strategies for climate change journalism. Asia Pacific Report. Retrieved from https://asiapacificreport.nz/2016/05/12/call-for-new-mediastrategies-for-climate-change-journalism/

Hutt, K. (2017a, April 21). 'We have to act now' - Marshall Islanders blast Runit npollution. Asia Pacific Report. Retrieved from https://asiapacificreport.nz/2017/04/21/ we-have-to-act-now-marshall-islanders-blast-runit-n-pollution/

Hutt, K. (2017b, August 31). 'Live, thrive in a new place - financing Pacific climate adaptation. Asia Pacific Report. Retrieved from https://asiapacificreport.nz/2017/08/31/ live-thrive-in-a-new-place-financing-climate-adaptation-in-the-pacific/

Hutt, K. (2017c, December 31). The graduate reflections: Kendall Hutt. In Robie, D., Bearing Witness 2017: A Pacific Media Centre/Te Ara Motuhenga project (pp. 3-6). 
Auckland: Pacific Media Centre, Auckland University of Technology.

Hutt, K., \& Cleaver, J. (2017a, April 22). Climate change report will help countries cut emissions. Asia Pacific Report. Retrieved from https://asiapacificreport.nz/2017/04/22/ climate-report-author-challenges-inadequate-global-emissions-goal/

Hutt, K., \& Cleaver, J. (2017b, May 9). Destruction and construction - Tukuraki's lonely story of survival. Asia Pacific Report. [Multimedia]. Retrieved from https://asiapacificreport.nz/2017/05/09/destruction-and-construction-tukurakis-lonely-story-of-survival/

Ings, W. (2017). Disobedient teaching: Surviving and creating change in education. Dunedin: Otago University Press.

IPCC (Intergovernmental Panel on Climate Change). (2017). Draft sixth assessment report outline. Retrieved from www.ipcc.ch/news_and_events/PR092017_AR6_Scoping.shtml

Johansson-Fua, S. F. (2014). Kakarla research framework: A garland in celebration of a decade of rethinking education. In 'Otunuku, M., Nabobo-Baba, U., Johansson-Fua, S. F. (eds.), Of waves, winds \& wonderful things: A decade of rethinking Pacific education (pp. 50-60). Suva: University of the South Pacific Press.

Johnson, J. (2018, January 5). Corporate media 'failed to connect 2017's extreme weather top climate crisis: Study. Common Dreams. Retrieved from https://www.commondreams.org/news/2018/01/05/corporate-media-failed-connect-2017s-extremeweather-climate-crisis-study

Jose, C., Wall, K., \& Hinzel, J. H. (2015, July 3). This dome in the Pacific houses tons of radioactive waste - and it's leaking. The Guardian.com. Retrieved from https://www. theguardian.com/world/2015/jul/03/runit-dome-pacific-radioactive-waste

Loo, E. (2013). Bridging the cultural gaps in journalism training and education in Asia. Singapore: Konrad-Adenauer-Stiftung.

Lugo-Ocando, J., \& Nguyen, A. (2017). Developing news: Global journalism and the coverage of 'third world' development. Abingdon, UK: Routledge.

Lynch, J. (2014). A global standard for reporting conflict. Abingdon, UK: Routledge.

Morgan, W. (2017). Coal comfort: Pacific islands on collision course with Australia over emissions. Pacific Journalism Review, 23(1): 25-31. doi: 10.24135/pjr.v23i1.311

Nash, C. (2015). Atolls in the ocean - canaries in the mine? Australian journalism contesting climate change impacts in the Pacific. Pacific Journalism Review, 21(1), 79-97. doi: 10.24135/pjr.v21i1.149

Nash, C. (2017). What is journalism? The art and politics of a rupture. London, UK: Palgrave Macmillan.

NIWA (National Institute of Water and Atmospheric Research). (2017). Annual climate summary 2017: a year of weather extremes across New Zealand. Retrieved from www.niwa.co.nz/climate/summaries/annual-climate-summary-2017

Olausson. U. (2011). 'We're the ones to blame': Citizens' representations of climate change and the role of the media. Environmental Communication: A Journal of Nature and Culture, 5(3), 281-299, doi: 10.1080/17524032.2011.585026

Pacific Media Centre Newsdesk (2017, October 29). Fiji’s Tukuraki village moves to new site after landslide. Asia Pacific Report. Retrieved from https://asiapacificreport. nz/2017/10/29/fijis-devastated-tukuraki-village-moves-to-new-site-after-landslide/

Prasad, B. (2017, January 15). COP23 presidency - facing the gravity of the task for Fiji. Asia Pacific Report. Retrieved from https://asiapacificreport.nz/2017/01/15/bimanprasad-cop23-presidency-facing-the-gravity-of-the-task-for-fiji/

Robie, D. (2011). Iconic media environmental images of Oceania: Challenging corporate news for solutions. In Dreadlocks, 6/7, 25-49. Suva, Fiji: University of the South Pacific. 
Robie, D. (2013). The talanoa and the tribal paradigm. Reflections on cross-cultural reporting in the Pacific. Australian Journalism Review, 35(1): 43-58. Retrieved from https:// search.informit.com.au/documentSummary; $\mathrm{dn}=505272837623485$;res=IELLCC

Robie, D. (2014a). Don't spoil my beautiful face: Media, mayhem and human rights in the Pacific. Auckland, NZ: Little Island Press.

Robie. D. (2014b). 'Carbon colonialism': Pacific environmental risk, media credi -bility and a deliberative perspective. Pacific Journalism Review: Te Koakoa, 20(2), 59-75. doi: $10.24135 /$ pjr.v20i2.166

Robie, D. (2016). Bearing witness 2016: A Pacific Media Centre project. Unpublished report. Auckland: Pacific Media Centre, Auckland University of Technology.

Robie, D. (2017a). The insecurity legacy of the Rainbow Warrior affair: A human rights transition from nuclear to climate-change refugees. Pacific Dynamics: Journal of Interdisciplinary Research, 1(1), 34-53. https://ir.canterbury.ac.nz/handle/10092/13641

Robie, D. (2017b). Bearing witness 2017: A Pacific Media Centre/Te Ara Motuhenga climate project: Year Two: 31 December 2017. Auckland: Pacific Media Centre.

Robie, D., \& Chand, S. (2017). Bearing witness 2016: A Fiji climate change journalism case study. Pacific Journalism Review: Te Koakoa, 23(1), 186-205. doi: $10.24135 /$ pjr.v23i1.257

Romano, A. (2010). International journalism and democracy: Civic engagement models from around the world. Abingdon, UK: Routledge.

Ryan, Y. (2010). COP15 and Pacific Island states: A collective voice on climate change. Pacific Journalism Review, 16(1), 193-203.

Science Media Centre (2018, January 8). 2017 a year of extreme weather - expert reaction. Retrieved from www.sciencemediacentre.co.nz/2018/01/08/2017-yearextreme-weather-expert-reaction/

Shaw, I.S. (2011). 'Human rights journalism': A critical conceptual framework of a complementary strand of peace journalism. In Shaw, I.S., Lynch, J., \& Hackett, R.A. (eds.), Expanding peace journalism: Comparative and critical approaches (pp. 96121). Sydney: Sydney University Press.

Shaw, I.S., Lynch, J., \& Hackett, R.A. (eds.), Expanding peace journalism: Comparative and critical approaches. Sydney: Sydney University Press.

Singh, S. (2017, October 18). Shailendra Singh: How journalists can walk the Pacific climate change talk. Asia Pacific Report. Retrieved from https://asiapacificreport.nz/2017/10/18/ shailendra-singh-how-journalists-can-walk-the-pacific-climate-change-talk/

SPREP launches new 10-year strategic plan. (2017, March 6). Secretariat of the Pacific Regional Environment Programme (SPREP). Retrieved from http://www.sprep.org/ news/sprep-launches-new-10-year-strategic-plan

SPREP Strategic Plan 2011-2015. (2011). Secretariat of the Pacific Regional Environment Programme (SPREP). Retrieved from http://www.sprep.org/att/publication/000921 SPREPStrategicPlan2011_2015.pdf

SPREP Strategic Plan 2017-2026. (2017). Secretariat of the Pacific Regional Environment Programme (SPREP). Retrieved from https://www.sprep.org/attachments/ Publications/Corporate Documents/strategic-plan-2017-2026.pdf

Temple, J. (2018, January $\overline{4})$. The year climate change began to spin out of control. MIT Technology Review. Retrieved from www.technologyreview.com/s/609642/the-yearclimate-change-began-to-spin-out-of-control/

Timperley, J. (2017, November 19). COP23: Key outcomes agreed at the UN talks in Bonn. Carbon Brief. Retrieved from www.carbonbrief.org/cop23-key-outcomesagreed-un-climate-talks-bonn 
Tropical Cyclone Winston Slams Fiji (2016, February 20). Earth Observatory (NASA). Retrieved from https://earthobservatory.nasa.gov/NaturalHazards/view.php?id=87562

Tukuraki village relocation (2016, July 21). Pacific Community website [Blog]. Retrieved from www.spc.int/blog/tukuraki-village-relocation/

Ugavule, E. (n.d.). About talanoa. Talanoa.com.au. Retrieved from http://talanoa.com. $\mathrm{au} / \mathrm{about} /$

UNDP Sustainable Development Goals. (2012). United Nations Development Programme (UNDP). Retrieved from www.undp.org/content/undp/en/home/sustainabledevelopment-goals.html

UNFCCC (2017a, November 13). Gender and climate change. United Nations Framework Convention on Climate Change. [Draft decision]. FCCC/SBI/2017/L.29. Retrieved from http://unfccc.int/resource/docs/2017/sbi/eng/129.pdf

UNFCCC (2017b, August 25). Local communities and indigenous peoples platform: proposals on operationalization based on the open multi-stakeholder dialogue and submissions. FCCC/SBSTA/2017/6. Retrieved from http://unfecc.int/resource/ docs/2017/sbsta/eng/06.pdf

Walsh, K. J. E., McInnes, K. L., \& McBride, J. L. (2011). Climate change impacts on tropical cyclones and extreme sea level as in the South Pacific - a regional assessment. Global and Planetary Change, 80: 149-164. Retrieved from 10.1016/j. gloplacha.2011.10.006

Webster, B. (2017, November 18). Fijian storytelling can save the world, says UN. The New York Times. Retrieved from www.thetimes.co.uk/article/fijian-storytelling-cansave-world-says-un-gxx 5t6zmr

\section{Acknowledgements}

An earlier version of this article was presented at the Second Pacific Climate Change Conference at Te Papa Tongarewa, Wellington, 21-23 February 2018, has been prepared with the assistance of Sarika Chand, then communication sofficer of the Pacific Centre for the Environment and Sustainable Development (PaCE-SD) at the University of the South Pacific, Fiji; USP Journalism Programme coordinator DrShailendra Singh; AUT's Te Ara Motuhenga team leader Jim Marbrook; and AUT graduate journalists Julie Cleaver and Kendall Hutt. The author thanks them for their contribution. The Bearing Witness project was assisted with a small grant from AUT's Pacific Media Centre.

Dr David Robie is professor of communication studies and director of the Pacific Media Centre at Auckland University of Technology. He is also founding editor of Pacific Journalism Review and author of several books on media and politics in the Asia-Pacific region.

david.robie@aut.ac.nz 


\begin{tabular}{|c|c|c|c|c|}
\hline Date & Topic & Format & Journalist & Publication \\
\hline $\begin{array}{l}12 \text { April } \\
2017\end{array}$ & $\begin{array}{l}\text { Project preview: Pacific climate } \\
\text { Bearing Witness } 2017: ' \text { 'We're } \\
\text { running out of time' }\end{array}$ & $\begin{array}{l}\text { Video } \\
\text { (101vviews) }\end{array}$ & $\begin{array}{l}\text { Kendall Hutt } \\
\text { Julie Cleaver }\end{array}$ & $\begin{array}{l}\text { PMC TouTube channel ('We're running out of } \\
\text { time', 2m57s), Asia Pacific Report } \\
\text { www.youtube.com/watch?v=R7Mhg33-67A }\end{array}$ \\
\hline $\begin{array}{l}13 \text { April } \\
2017\end{array}$ & $\begin{array}{l}\text { AUT journalists head off to Fiji for } \\
\text { Bearing Witness climate project }\end{array}$ & Text, video (162t) & Team & Asia Pacific Report \\
\hline $\begin{array}{l}18 \text { April } \\
2017\end{array}$ & $\begin{array}{l}\text { Fiji needs better planningto } \\
\text { reduce climate change impact, } \\
\text { says researcher }\end{array}$ & $\begin{array}{l}\text { Text, images } \\
(1145 \mathrm{t}, 183 \mathrm{v})\end{array}$ & $\begin{array}{l}\text { Julie Cleaver } \\
\text { Kendall Hutt }\end{array}$ & Asia Pacific Report \\
\hline $\begin{array}{l}21 \text { April } \\
2017\end{array}$ & $\begin{array}{l}\text { 'We have to act now'- Marshall } \\
\text { Islanders blast Runit n pollution }\end{array}$ & $\begin{array}{l}\text { Text, images } \\
(486 \mathrm{t})\end{array}$ & Kendall Hutt & Asia Pacific Report \\
\hline $\begin{array}{l}21 \text { April } \\
2017\end{array}$ & $\begin{array}{l}\text { Pacific climate change expert says } \\
\text { report will help countries meet } \\
\text { targets }\end{array}$ & $\begin{array}{l}\text { Video } \\
(129 \mathrm{v})\end{array}$ & Julie Cleaver & $\begin{array}{l}\text { PMC YouTube channel ('Pacific climate expert } \\
\text { syareport will help countries meet targets', } \\
\text { 1m32s). } \\
\text { https:/www.youtube.com/ } \\
\text { watch?v=zrlOJAwx4HA }\end{array}$ \\
\hline $\begin{array}{l}22 \text { April } \\
2017\end{array}$ & $\begin{array}{l}\text { Climate change report will } \\
\text { helpcountries cut emissions }\end{array}$ & $\begin{array}{l}\text { Text, video (365t, } \\
\text { 129v) }\end{array}$ & Kendall Hutt & $\begin{array}{l}\text { Asia Pacific Report (with the'Pacific limate } \\
\text { expert'video report above embedded) }\end{array}$ \\
\hline $\begin{array}{l}24 \text { April } \\
2017\end{array}$ & $\begin{array}{l}\text { USP student voices on climate } \\
\text { change }\end{array}$ & Video(441v) & Julie Cleaver & $\begin{array}{l}\text { PMCYouTube channel ('USP studentjournalist voices } \\
\text { on dlimate change', 2m47s) } \\
\text { https://www.youtube.com/ } \\
\text { watch?v=gasKsJ1rA7Y }\end{array}$ \\
\hline $\begin{array}{l}25 \text { April } \\
2017\end{array}$ & $\begin{array}{l}\text { Pacific student journalists pas- } \\
\text { sionate about reporting climate } \\
\text { change }\end{array}$ & $\begin{array}{l}\text { Text, video (354t, } \\
\text { 441v) }\end{array}$ & $\begin{array}{l}\text { Julie Cleaver } \\
\text { Kendall Hutt }\end{array}$ & $\begin{array}{l}\text { PMC YouTube channel ('USP studentjournalist voices } \\
\text { on dimate change', } 2 \mathrm{~m} 47 \mathrm{~s} \text { ). } \\
\text { https://wwww.youtube.com/ } \\
\text { watch?v=gasKsJ } 1 \text { rA7Y (embedded on Asia } \\
\text { Pacific Report) }\end{array}$ \\
\hline $\begin{array}{l}27 \text { April } \\
2017\end{array}$ & $\begin{array}{l}\text { Village relocation provides new hope } \\
\text { for Fiji's devastated Tukuraki }\end{array}$ & $\begin{array}{l}\text { Text, video } \\
\text { (276t) }\end{array}$ & $\begin{array}{l}\text { Julie Cleaver } \\
\text { Kendall Hutt }\end{array}$ & AsiaPacific Report \\
\hline 6 May 2017 & $\begin{array}{l}\text { Destruction and construction: The } \\
\text { story of Tukuraki village }\end{array}$ & No statistics & $\begin{array}{l}\text { Kendall Hutt } \\
\text { Julie Cleaver }\end{array}$ & DebateMagazine \\
\hline 8 May 2016 & Fiji's Tukuraki after the landslide & Video (328tv) & Julie Cleaver & $\begin{array}{l}\text { PMCYouTube channel ('Fiji's Tukuraki after the } \\
\text { landslide',3m28s). } \\
\text { https://www.youtube.com/ } \\
\text { watch?v=GOweZjJik-I }\end{array}$ \\
\hline 9 May 2017 & $\begin{array}{l}\text { Destruction and construction- } \\
\text { Tukuraki's lonely story of survival }\end{array}$ & $\begin{array}{l}\text { Text, images, } \\
\text { video }(413 t, 328 v)\end{array}$ & $\begin{array}{l}\text { Kendall Hutt } \\
\text { Julie Cleaver }\end{array}$ & $\begin{array}{l}\text { PMCYouTube channel ('Fiji's Tukurakiafter the } \\
\text { landslide',3m28s). } \\
\text { https://wwww.youtube.com/ } \\
\text { watch?v=GOweZjik-I (embedded on Asia } \\
\text { Pacific Report as above) }\end{array}$ \\
\hline 1 June 2017 & $\begin{array}{l}\text { Destruction and construction- } \\
\text { Tukuraki's lonely story of survival }\end{array}$ & $\begin{array}{l}\text { Text, images, } \\
\text { video (53v) }\end{array}$ & $\begin{array}{l}\text { Kendall Hutt } \\
\text { Julie Cleaver }\end{array}$ & Wansolwara (University of South Pacific) \\
\hline \multirow[t]{2}{*}{$\begin{array}{l}12 \text { Dec } \\
2017\end{array}$} & $\begin{array}{l}\text { Dart AsPachonors Pacific Media } \\
\text { Centre with trauma award }\end{array}$ & No statistics & Dart Team & Dart Asia Pacific Centre for Journalism and Trauma \\
\hline & & $\begin{array}{l}\text { Total views 7,957 } \\
\text { (11 March 2018) }\end{array}$ & & $\begin{array}{l}\text { All items sourced at the Bearing Witness projectin as- } \\
\text { sociation with the Pacific Centre for the Environment- } \\
\text { Sustainable Development-PACE-SD, University of } \\
\text { theSouth Pacific): } \\
\text { http://asiapacificreport.nz/category/cli- } \\
\text { mate/bearing-witness/ } \\
\text { Fiji Report'Bearing Witness', 2016-17 on Storify } \\
\text { (7,544 views): } \\
\text { https://storify.com/pacmedcentre/fiji-report- } \\
\text { bearing-witness-2016 }\end{array}$ \\
\hline
\end{tabular}

